\title{
Detection of seasonal cycles of erosion processes in a black marl gully from a time series of high-resolution digital elevation models (DEMs)
}

\author{
Jacques Bechet ${ }^{1, \dagger}$, Julien Duc ${ }^{1}$, Alexandre Loye ${ }^{1}$, Michel Jaboyedoff ${ }^{1}$, Nicolle Mathys ${ }^{2}$, \\ Jean-Philippe Malet ${ }^{3}$, Sébastien Klotz ${ }^{2}$, Caroline Le Bouteiller ${ }^{2}$, Benjamin Rudaz ${ }^{1}$, and \\ Julien Travelletti ${ }^{3, a}$ \\ ${ }^{1}$ University of Lausanne, Risk-group - ISTE - Institute of Earth Sciences, Lausanne, Switzerland \\ ${ }^{2}$ IRSTEA Grenoble, Unité de recherche Erosion Torrentielle, Neige et Avalanches, BP 76, \\ 38402 Saint Martin d'Hères, France \\ ${ }^{3}$ Institut de Physique du Globe de Strasbourg, CNRS UMR 7516, Ecole et Observatoire des Sciences de la \\ Terre, Université de Strasbourg, 5 rue Descartes, 67084 Strasbourg, France \\ anow at: BEG - Bureau d'Etudes Géologiques SA, Rue de la Printse 4, 1994 Aproz, Switzlerland \\ $\dagger$ deceased, 28 March 2015 \\ Correspondence to: Michel Jaboyedoff (michel.jaboyedoff@unil.ch)
}

Received: 1 December 2015 - Published in Earth Surf. Dynam. Discuss.: 18 December 2015

Revised: 12 August 2016 - Accepted: 19 September 2016 - Published: 19 October 2016

Abstract. The Roubine catchment located in the experimental research station of Draix-Bléone (south French Alps) is situated in Callovo-Oxfordian black marls, a lithology particularly prone to erosion and weathering processes. For 30 years, this small watershed $(0.13 \mathrm{ha}$ ) has been monitored for analysing hillslope processes on the scale of elementary gullies.

Since 2007, surface changes have been monitored by comparing high-resolution digital elevation models (HRDEMs) produced from terrestrial laser scanner (TLS). The objectives are (1) to detect and (2) to quantify the sediment production and the evolution of the gully morphology in terms of sediment availability/transport capacity vs. rainfall and runoff generation. Time series of TLS observations have been acquired periodically based on the seasonal runoff activity with a very high point cloud density ensuring a resolution of the digital elevation model (DEM) on the centimetre scale. The topographic changes over a time span of 2 years are analysed.

Quantitative analyses of the seasonal erosion activity and of the sediment fluxes show and confirm that during winter, loose regolith is created by mechanical weathering, and it is eroded and accumulates in the rills and gullies. Because of limited rainfall intensity in spring, part of the material is transported in the main gullies, which are assumed to be a transport-limited erosion system. In the late spring and summer the rainfall intensities increase, allowing the regolith, weathered and accumulated in the gullies and rills during the earlier seasons, to be washed out. Later in the year the catchment acts as a sediment-limited system because no more loose regolith is available. One interesting result is the fact that in the gullies the erosion-deposition processes are more active around the slope angle value of $35^{\circ}$, which probably indicates a behaviour close to dry granular material.

It is also observed that there exist thresholds for the rainfall events that are able to trigger significant erosion; they are above $9 \mathrm{~mm}$ rainfall or of an intensity of more than $1 \mathrm{~mm} \mathrm{~min}^{-1}$, values which can vary if antecedent precipitation is significant within the last 5 days.

This study improves knowledge of the spatial distribution of erosion seasonality in badlands and demonstrates the potential of careful 3-D high-resolution topography using TLS to improve the understanding of erosive processes. 


\section{Introduction}

This study is integrated into the cross-disciplinary research activities conducted in the Draix-Bléone catchments (SOERE-RBV, i.e. network of catchments for the study of the critical zone; see http://portailrbv.sedoo.fr/), composed of seven nested catchments characterized by several sizes and types of vegetation cover. This work focuses on the analysis of the processes controlling the annual pattern of erosion rates in elementary gullies (Richard, 1997; Meunier and Mathys, 1995; Mathys et al., 2005).

The region of Draix, where the study was conducted, is located within Jurassic, black marls of Callovo-Oxfordian age (also called Terres Noires), which cover large areas in south-east France. The badlands landscape observed in these clay-shale catchments is the result of the conjunction of favourable lithological and climatic factors. Freeze-thaw and wetting-drying cycles progressively disintegrate the black marl formation, thus favouring the annual development of a weathered marly layer exposed to surface runoff erosion and shallow landslides (Antoine et al., 1995; Maquaire et al., 2003). The weathered marls can be mobilized by Hortonian runoff, especially during high-intensity rainfalls in summer. This causes flash floods and hyperconcentrated flows, inducing significant problems in sedimentation reservoirs and river systems (Oostwoud Wijdenes and Ergenzinger, 1998; Descroix and Olivry, 2002). Saturation of the weathered marl layers can also locally trigger shallow landslides supplying high sediment loads to the basins. In addition, rain infiltration in the fractured marl bedrock contributes to the triggering of larger landslides whose geometry is controlled by the bedding and the discontinuities. There is a strong seasonal difference between the rates of surface erosion processes in summer and winter (Descroix and Gautier, 2002; Descroix and Mathys, 2003); the erosion processes therefore have an annually cyclic activity pattern.

A terrestrial laser scanner (TLS) is a powerful tool to monitor erosion processes on the gully scale at a relatively low cost (Perroy et al., 2010; Jaboyedoff et al., 2012) where high spatial-resolution data on surface changes are needed (Jacome, 2009). Such high-resolution mapping of erosion rates on a fine (e.g. seasonal) temporal scale for an entire catchment is innovative and represents considerable progress in the field of erosion assessment (Lopez Saez et al., 2011). Preliminary studies show a great potential of TLS to measure and map surface erosion (Puech et al., 2009) since it can detect millimetre-scale changes at short-range distances $(50 \mathrm{~m}$; Abellán et al., 2009).

In this study, time series of intra-annual TLS observations are used to quantify surface erosion. The main objectives are (i) to create erosion and deposition maps for every season; (ii) to estimate the sediment budget and evaluate the accuracy of the volume calculation on the catchment scale by comparing it to sediment trap observation; and (iii) to propose a conceptual model describing the observed seasonal pattern of erosion and deposition. The results allow the identification and quantification of the topographic changes in the catchment in terms of regolith development, slope transfer processes, and transient storages of sediment within the rills and gullies. This is placed in the context of previous work on similar black marl slopes, confirming the high impact of season on erosion process cycles.

\section{Physio-geographic settings of the study area: the Roubine catchment}

\subsection{Morphology}

The research has been conducted in the Draix-Bléone experimental catchments (SOERE RBV network, Systèmes d'Observation et d'Expérimentation pour la Recherche en Environnement Réseau de Bassins Versants) in south-east France, near the city of Digne-les-Bains (Alpes-de-HauteProvence). Draix-Bléone observatory is composed of seven small mountain watersheds. It was created by IRSTEA (Institut national de recherche en sciences et technologies pour l'environnement et l'agriculture) in 1983 in order to better understand erosion and sediment transfer processes, including hyperconcentrated floods, and to improve the design of protections in response to erosion processes. The experimental site selected for this work is the Roubine elementary catchment (Fig. 1), which is the smallest $\left(1330 \mathrm{~m}^{2}\right)$ monitored watershed of the Draix experimental site (Mathys et al., 2003). No human activity has been conducted within the gully since the setup of the observatory in 1983 .

This elementary watershed has a typical badland morphology, characterized by v-shaped gullies, steep slopes (35 to $45^{\circ}$ ), and low-vegetation coverage (ca. 20\%). The Roubine elementary catchment is made up of one main gully that crosses it from east to west. This gully separates the catchment into a north- and a south-facing slope. On the southfacing slope, a secondary gully crosses diagonally in the direction north-east to south-west and joins the main gully at the catchment outlet. Both north- and south-facing slopes have with many small gullies and rills of decametric widths. A few unweathered marl outcrops can be observed in the steepest sections of both slopes. On these outcrops, the dip of the black marl formation is $25^{\circ}$ to the east, which has an impact on erosion processes (Esteves et al., 2005; Mathys et al., 2005). The scarce vegetation cover is made up of a few black pines (Pinus nigra) and tufts of grass restricted to the flatter interfluves near the sediment trap and on the top of the crests.

A sediment trap, a stream gauge and an automatic sampler are installed at the bottom of La Roubine in order to monitor the sediment yield and the water discharge (Mathys et al., 

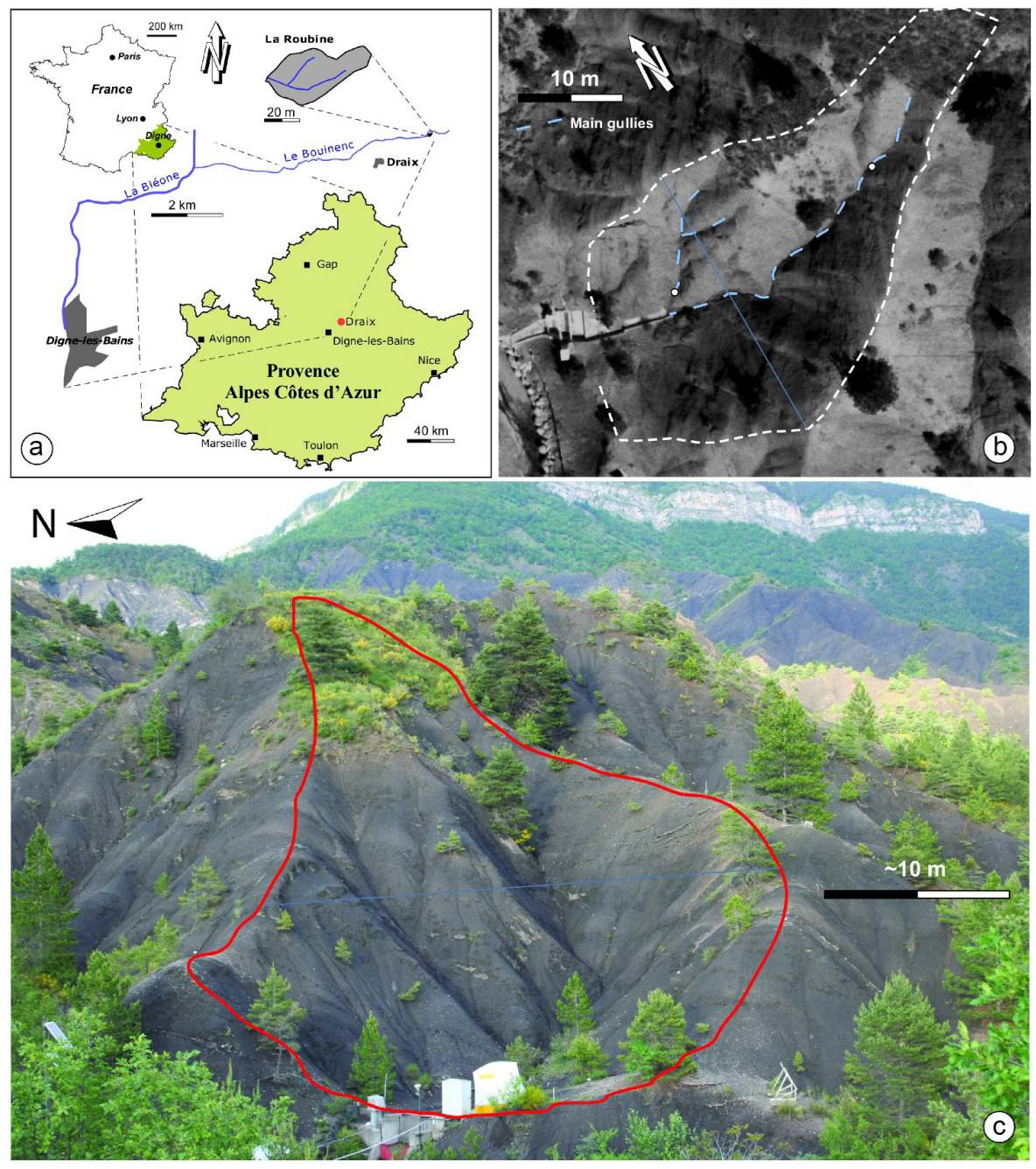

Figure 1. Location and picture of La Roubine. (a) Location of La Roubine catchment. (b) Aerial image of La Roubine. (c) Photograph of the Roubine catchment (1 June 2011) with the contours indicated in red line. Foreground: La Roubine catchment characterized by a typical badland morphology, many small-scale rills and gullies, steep slopes, and scarce vegetation. The catchment outlet is located at the western extremity with the sediment trap and the limnigraph. Background: surrounding badlands and limestone ridge.

2003). Rainfall observations are collected by a rain gauge located $20 \mathrm{~m}$ from the Roubine outlet.

\subsection{Geology}

Large areas of south-east France are covered by black marls, which outcrop over more than $10000 \mathrm{~km}^{2}$ in the watershed of the Durance river (Légier, 1977; Phan and Antoine, 1994; Mathys et al., 1996). This sedimentary lithology is composed of alternating marl and limestone sequences whose ages range from Lias to Cretaceous. The marly sequence which outcrops in the Draix-Bléone catchments is from the Bathonian to Oxfordian, and its thickness can exceed $2000 \mathrm{~m}$ in some places (Antoine et al., 1995; Maquaire et al., 2003). These black marls are overlain by limestones, creating cliffs in the upper part of the Draix catchment (Ballais, 1999).
The mean erosion rate of the black marls averaged over 3 years $(1985-1987)$ is $8 \mathrm{~mm} \mathrm{yr}^{-1}$, which is approximately $100 \mathrm{tha}^{-1} \mathrm{yr}^{-1}$ (Olivry and Hoorelbeck, 1989) and more specifically $100 \mathrm{tha}^{-1} \mathrm{yr}^{-1}$ or $13 \mathrm{~mm} \mathrm{yr}^{-1}$ for the Roubine catchment.

\subsection{Climate}

The specific features of a Mediterranean mountain climate influence slope erosion rates with strong seasonal and yearly differences in temperature and rainfall. At Draix, the mean annual rainfall is $920 \mathrm{~mm}$, with an interannual variability of nearly $400 \mathrm{~mm}$ over the period 1970-2000. The summer is relatively dry, but several heavy thunderstorms can occur, the intensity of which sometimes exceeds $60 \mathrm{~mm} \mathrm{~h}^{-1}$ (Richard, 1997) and can even reach more than $100 \mathrm{~mm} \mathrm{~h}^{-1}$ 
during a few minutes (Yamakoshi et al., 2009), i.e. 210, $138,90,74$ and $45 \mathrm{~mm} \mathrm{~h}^{-1}$ respectively during $1,5,15$, 30 and 60 min (Mathys, 2006). These events trigger hyperconcentrated flows characterized by suspended sediment discharge of up to $800 \mathrm{~g} \mathrm{~L}^{-1}$ (Olivier, 1999). Micro-debris flows (MDFs) have also been observed (Oostwoud Wijdenes and Ergenzinger, 1998) and clearly associated with high erosive events (Yamakoshi et al., 2009, 2010). Hailstorms are not unusual. During spring and autumn seasons, the rainfall amounts are at their maxima. During the winter, very small amounts of rainfall are measured, but over 100 cycles of freezing-thawing are observed (Oostwoud Wijdenes and Ergenzinger 1998; Rovera and Robert, 2005). A snow cover can form but does not usually last the whole winter. The average yearly air temperature is $10.9^{\circ} \mathrm{C}$ with a standard deviation of $8.7^{\circ} \mathrm{C}$ (based on daily average temperature) over the period 1970-2000.

\section{Methodology}

\subsection{TLS measurements}

The study site has been monitored using a TLS. This remote scanning device is a monochromatic laser pulse transmitter/receiver. The laser beam pulses are oriented using mirrors or by moving the laser source mechanically or both. The time of flight (TOF) is the time for the pulses to travel the double distance $(d)$, at the speed of light $(c)$, to the reflecting surfaces $(2 \times d=c \times$ TOF $)$. In practice the laser has a footprint that increases in diameter with increasing distances to the target. The operation is repeated millions of times giving access to a very dense grid of $X Y Z$ points (Shan and Toth, 2008). Two types of TLS were used for this study: TLS1 is an Ilris 3-D (Optech, Canada) scanner, and TLS2 is a TotalStation II (Leica, Germany) scanner. The TLS1 laser is infrared $(1535 \mathrm{~nm})$ and the performance coming from the manufacturer indicates that it produces data with an accuracy of $8 \mathrm{~mm}$ with a spot diameter of $22 \mathrm{~mm}$ at $100 \mathrm{~m}$. The TLS2 laser is in the green wavelength (only information available from the manufacturer) with $6 \mathrm{~mm}$ accuracy and a $6 \mathrm{~mm}$ spot size at $50 \mathrm{~m}$.

\subsection{Data acquisition and processing}

Twelve TLS campaigns were performed from 9 May 2007 to 4 November 2010 (Table 1). The data of the years 2007 and 2008 are sparser as the methodology and protocol were being developed. In 2009 and 2010, TLS data were acquired more regularly throughout the year in order to take into account more precisely the influences of the seasonal rainfall.

For each TLS campaign, the measurements were performed from up to five different scan positions in order to minimize shadow areas. However, some shadow areas still remain because of the presence of foreground in the line of sight of the scanner or of vegetation. All scan spatial resolu- tions are less than $10 \mathrm{~mm}$ at a $50 \mathrm{~m}$ distance range. The point cloud density is very high for all the time series and ranges from 0.3 to $3 \mathrm{pts} \mathrm{cm}^{-2}$.

The software Polyworks V. 9.1.8. (InnovMetric, 2010) was used to process the TLS point clouds. First, the vegetated areas are deleted from the raw point clouds in order to keep only the bare soil surface for the analysis. The scans of each campaign are then aligned using the iterative closest point (ICP) procedure (Chen and Medioni, 1992; Besl and McKay, 1992) to obtain a point cloud of the entire catchment. The TLS campaigns are aligned to a reference campaign (e.g. June 2009) using eight white $180 \mathrm{~mm}$ diameter styrene spheres located around the catchment since 2008. Depending on the TLS distance of acquisition and the overlapping of the different scenes, the final point cloud density is variable; thus, each TLS point cloud has been interpolated into a homogeneous $0.02 \mathrm{~m}$ high-resolution digital elevation model (HRDEM) using the Surfer 8 (GoldenSoftware) inverse distance method (Shepard, 1968). A high-density point cloud produces an over-defined problem during the interpolation due to too many points being present in one grid cell (Schürch et al., 2011). If we do not consider the systematic error (which will be discussed separately later), the law of large numbers (Kromer et al., 2015) indicates that the accuracy will increase when the average is taken, assuming that the surface is locally planar, on the centimetre scale. As an example, considering that the lower accuracy for one point is $\sigma_{1}=8 \mathrm{~mm}$. Performing an average on a surface area of $4 \mathrm{~cm}^{2}(2 \times 2 \mathrm{~cm})$ with densities ranging from 0.3 to 3 pts $\mathrm{cm}^{-2}\left(n=1.2\right.$ and $12 \mathrm{pts}$ in $\left.4 \mathrm{~cm}^{2}\right)$ provides an accuracy ranging from 6.7 to $2.3 \mathrm{~mm}$ because $\sigma_{n}$ is given by $\left(\sigma_{1}^{2} / n\right)^{0.5}$, assuming that the point cloud is well georeferenced. In some cases, TLS data can allow detecting movements below $1 \mathrm{~mm}$ because of the law of large numbers (Kromer et al., 2015).

We do not consider horizontal error for two main reasons: (1) the effect of the slope orientation on the measurement of point location is very similar for each scan (the average slope does not change significantly between scans); (2) when merging the scan with ICP, the errors between scans include their horizontal components. This error does not exceed the thresholds we used for detecting erosive processes (see Sects. 3.5 and 4.1). Assuming the systematic errors caused by slope orientation are similar (except for identified other problems) for all scans, we do not tackle this topic in more detail.

\subsection{Calculation of vertical difference HRDEMs: location of erosion-prone areas and quantification of volume changes}

To quantify and map the erosion and deposition through time, the most recent HRDEM was subtracted from an earlier HRDEM (DeRose et al., 1998). The resulting elevation changes have negative pixel values representing erosion and positive pixel values representing deposition. 
(a) May 2007 to June 2007

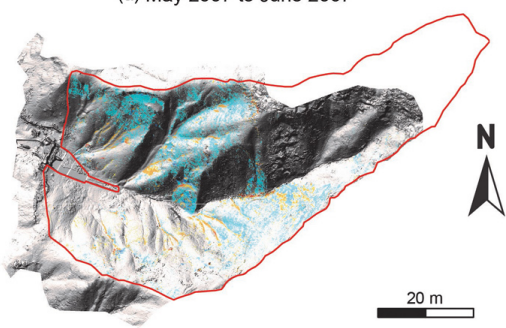

(c) June 2008 to April 2009

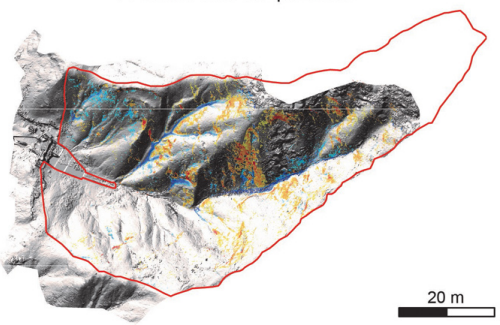

(e) June 2009 to August 2009

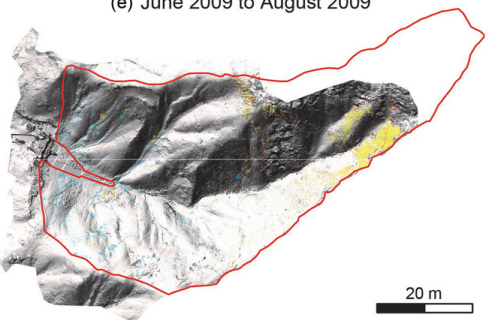

(g) November 2009 to March 2010

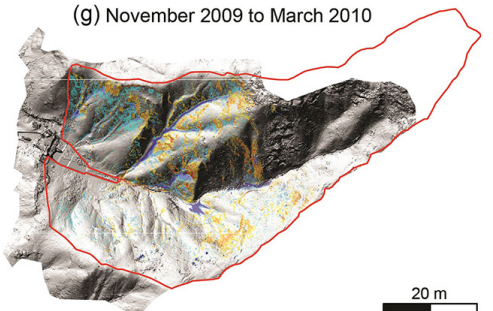

(i) May 2010 to June 2010
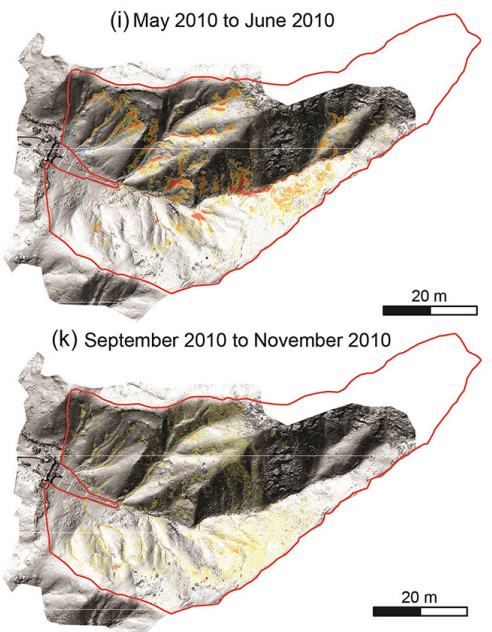

(b) June 2007 to June 2008

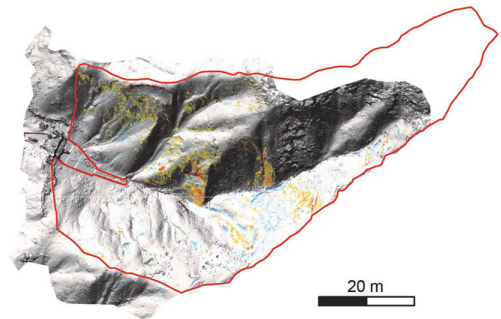

(d) April 2009 to June 2009

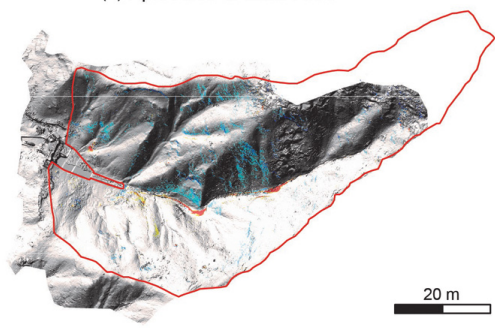

(f) August 2009 to November 2009

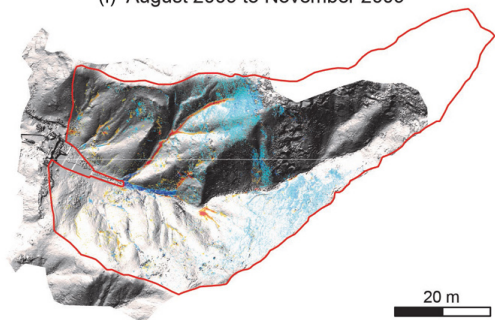

(h) March 2010 to May 2010
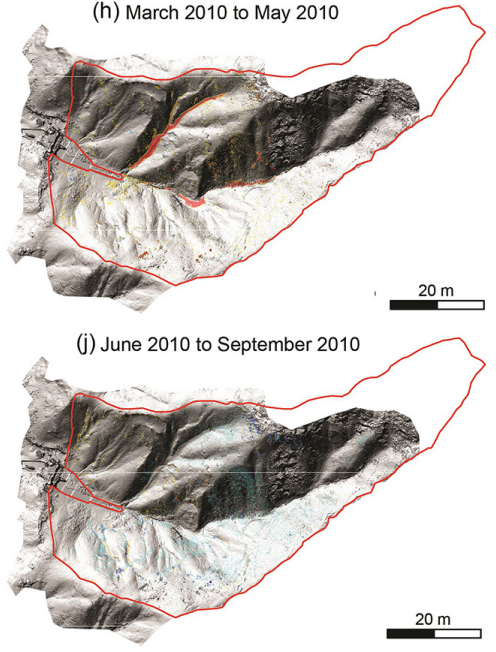

Topographic changes [m]
$\mathbf{N}$

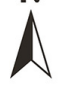

$20 \mathrm{~m}$

Figure 2. Observed height differences for the period 2007-2010 highlighting the soil surface changes of La Roubine catchment. The red outline indicates the boundary of the catchment (see large version in the Supplement). 
Table 1. Characteristics of the TLS alignment with, for each time period, the information on the number of scans used to create a scene. The table indicates standard deviation (SD) of the point from the surface matched (point-to-surface ICP), the mean difference between two scans (either used to align with period or for inter-period comparison), the average point density used, and the standard deviation of the average mean difference.

\begin{tabular}{|c|c|c|c|c|c|c|c|c|c|}
\hline \multirow[b]{2}{*}{ Period of time } & \multicolumn{5}{|c|}{ Alignment scans of each period } & \multicolumn{4}{|c|}{ Inter-period } \\
\hline & $\begin{array}{l}\text { Num. } \\
\text { scans }\end{array}$ & $\begin{array}{l}\text { SD pts- } \\
\text { surf. (m) }\end{array}$ & $\begin{array}{l}\text { mean diff. } \\
\text { align. }(\mathrm{m})\end{array}$ & $\begin{array}{l}\text { Pt density } \\
\left(\text { pts cm }{ }^{-2}\right)\end{array}$ & $\begin{array}{l}\text { SD mean } \\
\text { diff. }(m)\end{array}$ & $\begin{array}{r}\text { SD inter } \\
\text { period }(m)\end{array}$ & $\begin{array}{r}\text { Mean diff. } \\
\text { inter-period }(\mathrm{m})\end{array}$ & $\begin{array}{l}\text { Pt density } \\
\left(\text { pts } \mathrm{cm}^{-2}\right)\end{array}$ & $\begin{array}{r}\text { SD mean } \\
(\mathrm{m})\end{array}$ \\
\hline May 2007 (O) & 3 & $6.00 \mathrm{E}-03$ & $1.00 \mathrm{E}-05$ & $1.26 \mathrm{E}+00$ & $2.09 \mathrm{E}-06$ & $1.50 \mathrm{E}-02$ & $-2.70 \mathrm{E}-04$ & $7.24 \mathrm{E}+01$ & $3.40 \mathrm{E}-05$ \\
\hline Jun 2007 (O) & 1 & - & - & $7.76 \mathrm{E}-01$ & - & $1.33 \mathrm{E}-02$ & $-6.00 \mathrm{E}-05$ & $4.98 \mathrm{E}+00$ & $1.07 \mathrm{E}-05$ \\
\hline Jun 2008 (O) & 3 & $7.00 \mathrm{E}-03$ & $2.00 \mathrm{E}-05$ & $1.37 \mathrm{E}+00$ & $2.27 \mathrm{E}-06$ & $6.94 \mathrm{E}-03$ & $-1.70 \mathrm{E}-04$ & $2.62 \mathrm{E}+00$ & $4.34 \mathrm{E}-06$ \\
\hline Apr $2009(\mathrm{O})$ & 6 & $1.20 \mathrm{E}-02$ & $3.40 \mathrm{E}-05$ & $1.49 \mathrm{E}+00$ & $3.05 \mathrm{E}-06$ & $5.47 \mathrm{E}-03$ & $-1.10 \mathrm{E}-04$ & - & - \\
\hline Jun $2009(\mathrm{O})$ & 4 & $4.60 \mathrm{E}-03$ & $7.00 \mathrm{E}-05$ & $1.32 \mathrm{E}+00$ & $1.27 \mathrm{E}-06$ & - & - & - & - \\
\hline Aug 2009 (O) & 7 & $5.20 \mathrm{E}-03$ & $8.00 \mathrm{E}-06$ & $1.59 \mathrm{E}+00$ & $1.32 \mathrm{E}-06$ & $5.56 \mathrm{E}-03$ & $-1.30 \mathrm{E}-04$ & - & - \\
\hline Nov 2009 (L) & 4 & $4.20 \mathrm{E}-03$ & $2.00 \mathrm{E}-05$ & $6.10 \mathrm{E}-01$ & $1.87 \mathrm{E}-06$ & $5.20 \mathrm{E}-03$ & $2.80 \mathrm{E}-04$ & - & - \\
\hline Mar 2010 (L) & 3 & $3.40 \mathrm{E}-03$ & $4.30 \mathrm{E}-05$ & $3.48 \mathrm{E}-01$ & $2.02 \mathrm{E}-06$ & $3.85 \mathrm{E}-03$ & $3.80 \mathrm{E}-04$ & - & - \\
\hline May $2010(\mathrm{O})$ & 6 & $4.60 \mathrm{E}-03$ & $9.00 \mathrm{E}-06$ & $3.09 \mathrm{E}+00$ & $7.65 \mathrm{E}-07$ & $5.17 \mathrm{E}-03$ & $-8.00 \mathrm{E}-05$ & $8.69 \mathrm{E}+00$ & $3.27 \mathrm{E}-06$ \\
\hline Jun $2010(\mathrm{O})$ & 6 & $4.80 \mathrm{E}-03$ & $7.00 \mathrm{E}-06$ & $3.26 \mathrm{E}+00$ & $7.89 \mathrm{E}-07$ & $5.46 \mathrm{E}-03$ & $-2.20 \mathrm{E}-04$ & $9.99 \mathrm{E}+00$ & $1.52 \mathrm{E}-06$ \\
\hline Sep 2010 (L) & 3 & $2.60 \mathrm{E}-03$ & $-2.00 \mathrm{E}-06$ & $1.79 \mathrm{E}-01$ & $1.57 \mathrm{E}-06$ & $5.44 \mathrm{E}-03$ & $9.29 \mathrm{E}-03$ & - & - \\
\hline Nov 2010 (L) & 3 & $2.70 \mathrm{E}-03$ & $3.00 \mathrm{E}-05$ & $4.09 \mathrm{E}-01$ & $1.51 \mathrm{E}-06$ & $4.55 \mathrm{E}-03$ & $-3.50 \mathrm{E}-04$ & - & - \\
\hline
\end{tabular}

O: lidar Optech Ilris 3-D; L: lidar Leica TotalStation II.

Eleven differences between successive HRDEMs providing digital elevation models (DEMs) of differences (DoDs) have been calculated from 9 May 2007 to 4 November 2010 (Fig. 2). Because the occurrence of processes is strongly related to each season, the HRDEMs are sorted by seasonal periods. The mapping of the different erosion and deposition areas is carried out for each season by taking into account the DoDs of the corresponding seasons. These comparisons allow the detection and mapping of the most erosiondeposition-prone areas in the catchment (Fig. 3) and the characterization of the annual pattern of erosion (Betts and DeRose, 1999). These maps represent a synthesis of the DoDs (Fig. 2) showing the erosion or deposition areas. On these maps (Fig. 3), the erosion areas are displayed in orange and the deposition areas are in blue (see also the video in the Supplement).

To quantify the volume of soil surface changes, the elevation differences are summed and multiplied by the DEM squared cell resolution $\left(0.004 \mathrm{~m}^{2}\right)$. To obtain the sediment budget, the total volume of deposition is subtracted from the total volume of erosion. This calculation provides the final results of topographic changes in cubic metres. To minimize scan alignment inaccuracy on the quantification of the volumes, the topographic changes outside the active erosionprone areas previously mapped have been ignored. Finally, an average density of $1500 \mathrm{~kg} \mathrm{~m}^{-3}$ for the black marl deposits was measured in the sediment trap as proposed by Mathys et al. (1996). In addition, the volumes of sediment deposited in the sediment trap increased by $20 \%$ because an annual average of $20 \%$ of the total eroded sediment exits the catchment in water-suspended flows (Mathys, 2006). It must be noted that during major storm events, up to $40 \%$ of sediments can exit the catchment in hyperconcentrated flows
(Mathys, 2006). The corrected volumes are obtained using these two values and the results are used to calibrate the TLS volumes in order to take into account the expansion. This has been done because some vegetated areas and some occlusions exist which are not imaged by the scans (Tables 2 and 3). As a reminder, these corrections were performed because access to the Roubine catchment is prohibited. This allows us to also get a rough idea of the density of the eroded material. It changes throughout the year according to the seasons, indicating that in summer the density is close to the bedrock value (i.e. $2325 \mathrm{~kg} \mathrm{~m}^{-3}$ ) and during spring it is close to the sediment $1500 \mathrm{~kg} \mathrm{~m}^{-3}$.

\subsection{Slope gradient and aspect}

In order to evaluate the role of topographic proxies (slope angle, slope aspect, upstream contributing area (UCA), TOBIA index; Meentemeyer and Moody, 2000), the DoDs of each period are averaged on a $10 \mathrm{~cm}$ grid to reduce noisy values. Several topographic parameters are computed on the June 2010 topography, using ArcGIS (slope angle, aspect, and upstream contributing area) and Matlab (TOBIA). Gullies are identified as pixels with UCA values over $10 \mathrm{~m}^{2}$ with a $20 \mathrm{~cm}$ buffer to account for gully width. This distinguishes slopes from gullies.

The TOBIA index is computed assuming a uniform dip and dip direction of the black marls at $25^{\circ} / 86^{\circ}$, as observed in the field and computed using Coltop software (Jaboyedoff et al., 2007). 

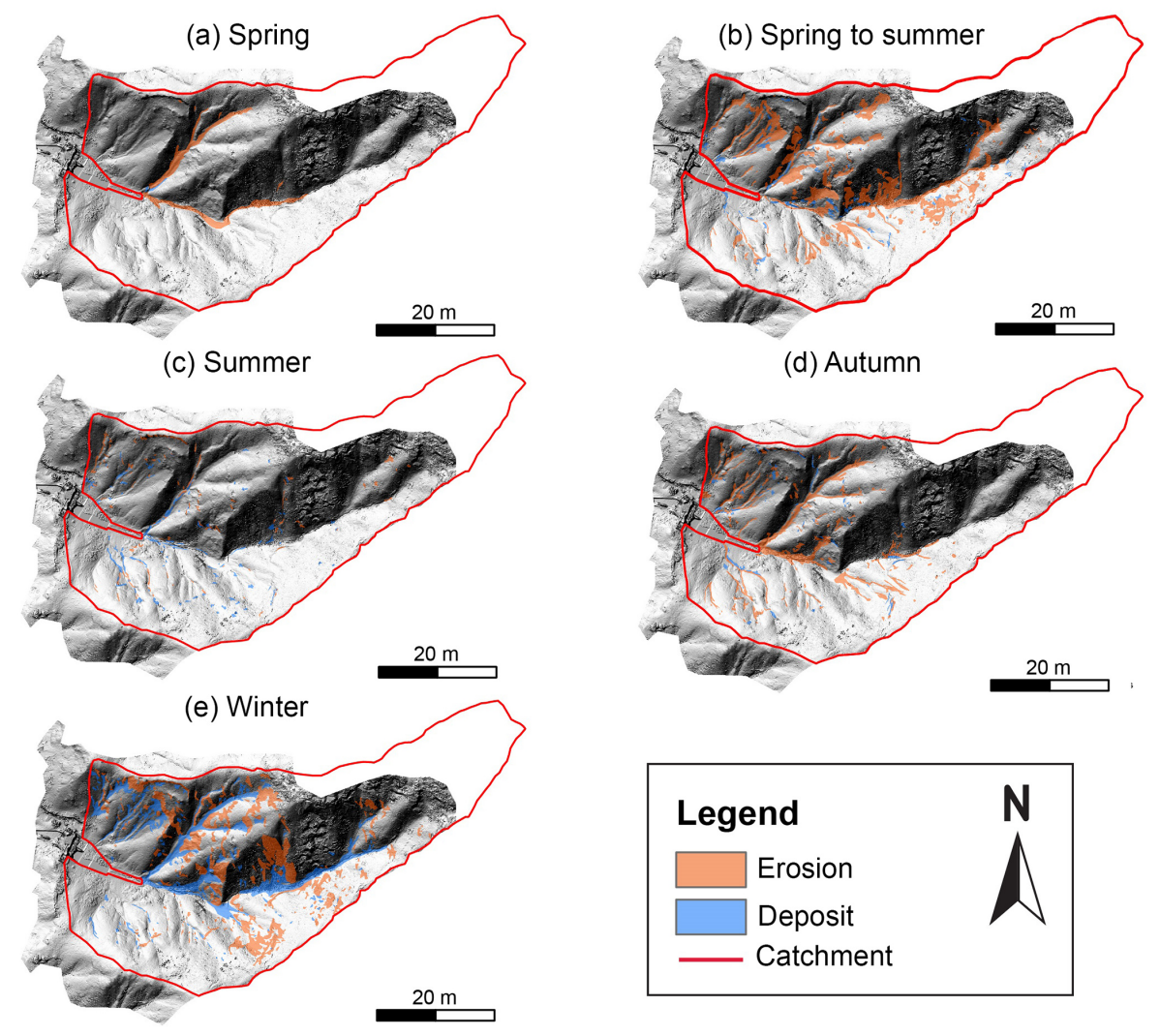

Figure 3. Typical pattern of slope activity (erosion in orange; deposition in blue) for each predefined season. The red outline indicates the boundary of the catchment (see also the video in the Supplement).

Table 2. Measured volume of erosion and deposition. In order to perform a comparison with Table $3,0.48 \mathrm{~m}^{3}$ have been added to the cumulative volume of the first period.

\begin{tabular}{|c|c|c|c|c|c|c|c|c|}
\hline Start date & End date & $\begin{array}{l}\text { Density } \\
\left(\mathrm{kg} \mathrm{m}^{3}\right)\end{array}$ & $\begin{array}{r}\text { Erosion } \\
\quad\left(\mathrm{m}^{3}\right)\end{array}$ & $\begin{array}{r}\text { Deposit } \\
\left(\mathrm{m}^{3}\right)\end{array}$ & $\begin{array}{r}\text { Balance } \\
\left(\mathrm{m}^{3}\right)\end{array}$ & $\begin{array}{r}\text { Cum. vol. } \\
\left(\mathrm{m}^{3}\right)\end{array}$ & $\begin{array}{l}\text { Vol. } \mathrm{yr}^{-1} \\
\left(\mathrm{~m}^{3} \mathrm{yr}^{-1}\right)\end{array}$ & $\begin{array}{r}\text { Erosion rate } \\
\left(\mathrm{mm} \mathrm{yr}^{-1}\right)\end{array}$ \\
\hline 14.04.2009 & 31.05 .2009 & 1500 & -0.56 & 0.27 & -0.30 & 0.78 & 6.04 & 4.54 \\
\hline 31.05 .2009 & 11.08 .2009 & 2325 & -0.38 & 0.38 & -0.01 & 0.78 & 0.03 & 0.02 \\
\hline 11.08.2009 & 03.11 .2009 & 1875 & -1.99 & 1.05 & -0.94 & 1.73 & 4.09 & 3.07 \\
\hline 03.11 .2009 & 23.03 .2010 & 1875 & -4.54 & 3.34 & -1.20 & 2.92 & 3.12 & 2.34 \\
\hline 23.03.2010 & 28.05 .2010 & 1500 & -2.74 & 0.02 & -2.72 & 5.64 & 15.05 & 11.32 \\
\hline 28.05 .2010 & 23.06 .2010 & 1500 & -6.29 & 0.26 & -6.03 & 11.68 & 84.71 & 63.69 \\
\hline 23.06 .2010 & 22.09 .2010 & 2325 & -0.42 & 0.05 & -0.37 & 12.04 & 1.47 & 1.10 \\
\hline \multirow[t]{2}{*}{ 22.09.2010 } & 04.11 .2010 & 1875 & -1.78 & 0.16 & -1.62 & 13.66 & 13.73 & 10.33 \\
\hline & \multicolumn{5}{|c|}{ Volume added for 14 April 2009} & 0.48 & & \\
\hline
\end{tabular}

\subsection{Sources of errors}

The use of TLS observations resulted in several sources of errors that were quantified. First, TLS measurements are affected by instrumental errors as described by Abellán et al. (2009). These authors showed, in particular, that when averaging point clouds, the detection of changes improved significantly. Second, some scans are also affected by deforma- tion due to atmospheric conditions. Third, some DoDs contain some misalignment characterized by slight tiling due to scan deformation and/or scan alignment inaccuracies; such a source of error is, for instance, clearly visible in Fig. 2f. The use of a high threshold value to validate DoD values to detect the process of erosion or deposition permits us to escape the problems of misalignment or atmospheric deformation (see below). In fact, the quality precision and precision of the two 
Table 3. Measured volume in the sediment trap.

\begin{tabular}{lrrlrr}
\hline Date & $\begin{array}{r}\text { Measured } \\
\text { volumes } \\
\left(\mathrm{m}^{3}\right)\end{array}$ & $\begin{array}{r}\text { Cumulative } \\
\text { volumes } \\
\left(\mathrm{m}^{3}\right)\end{array}$ & & $\begin{array}{r}\text { Measured } \\
\text { volumes } \\
\left(\mathrm{m}^{3}\right)\end{array}$ & $\begin{array}{r}\text { Cumulative } \\
\text { volumes } \\
\left(\mathrm{m}^{3}\right)\end{array}$ \\
\hline 26.01 .2009 & - & - & 13.02 .2010 & 1.42 & 5.6 \\
09.02 .2009 & 0.48 & 0.5 & 05.05 .2010 & 0.01 & 5.6 \\
17.04 .2009 & 0.67 & 1.2 & 07.05 .2010 & 0.01 & 5.6 \\
05.05 .2009 & 0.02 & 1.2 & 11.05 .2010 & 2.87 & 8.5 \\
02.07 .2009 & 0.20 & 1.4 & 17.05 .2010 & 0.01 & 8.5 \\
10.08 .2009 & 0.09 & 1.5 & 16.06 .2010 & 3.31 & 11.8 \\
20.08 .2009 & 0.02 & 1.5 & 24.08 .2010 & 0.49 & 12.3 \\
27.09 .2009 & 0.03 & 1.5 & 13.09 .2010 & 0.08 & 12.4 \\
28.09 .2009 & 0.24 & 1.7 & 22.09 .2010 & 0.02 & 12.4 \\
22.10 .2009 & 1.72 & 3.5 & 27.09 .2010 & 0.32 & 12.7 \\
04.11 .2009 & 0.61 & 4.1 & 05.10 .2010 & 1.74 & 14.5 \\
06.12 .2009 & 0.12 & 4.2 & 25.10 .2010 & 0.01 & 14.5 \\
\hline
\end{tabular}

successive alignment procedures, i.e. the scan merging and the "georeferencing", vary from one measurement campaign to another as the TLS instrument, the scan deformation, and the spatial resolution were different (Table 2).

A possible procedure to estimate the overall errors is to define the quality of (1) the alignments for each campaign and (2) the alignment between campaigns. This corresponds to the measurement of the dispersion of the points between two merged scans (1). This is performed by identifying the areas that have not changed (fixed surfaces like the spheres, wall, etc.). The average distance between two scans and the associated standard deviation is measured using the point-tosurface method. A similar procedure can be applied to successive campaigns (2). Note that the averaging of the HRDEM allows us to reduce the noise and minimize other measurement errors.

\section{Results}

\subsection{Analysis of soil surface height differences}

DoDs outline the slope surface changes on a centimetre scale (Fig. 2). All the DoDs are presented in a plan view on a hillshade of the watershed. The eastern limit of the catchment lacks data because of dense vegetation cover. The differences under $1.8 \mathrm{~cm}$ are not displayed. This limit has been chosen according to a trial and error procedure and assuming that it contains in most cases above 3 times the maximum error of alignment of $6 \mathrm{~mm}$, except for the scans of 2007. A clustering of the height differences in three classes is proposed both for erosion and deposition: small height differences ranging from 1.8 to $4.0 \mathrm{~cm}$; moderate height differences ranging from 4.0 to $10.0 \mathrm{~cm}$; large height differences above $10.0 \mathrm{~cm}$ in absolute value. The erosion pattern is displayed in warm colours, while the deposition pattern is displayed in cold colours.

\subsection{Cartography and temporal pattern of erosion processes}

Five erosion patterns are distinguished for La Roubine catchment: winter, spring, late spring to early summer, summer, and autumn.

- The winter seasons erosion pattern is illustrated by the DoDs between 3 November 2009 and 23 March 2010 (Fig. 2g).

- The spring seasons erosion pattern is represented by DoDs between 14 April to 1 June 2009 and 23 March to 28 May 2010 (respectively Fig. 2d and h).

- The erosion pattern of late spring to early summer rainy season is illustrated by the DoDs between 9 May to 24 June 2007 and 28 May to 23 June 2010 (respectively Fig. 2a and i). In 2009, the rainfall amount in this season was $30 \%$ below average up to 20 December and $19 \%$ below average for the whole year, only thanks to some late precipitations in the last days of the calendar year, most probably snow. Thus no DoD corresponds to that period in 2009.

- The summer season erosion pattern is represented by DoDs between 1 June to 11 August 2009 and 23 June to 22 September 2010 (respectively Fig. 2e and j).

- The autumn season erosion pattern is represented by DoDs between 11 August to 3 November 2009 and 22 September to 4 November 2010 (respectively Fig. 2f and $\mathrm{k}$ ).

- During winter seasons (Fig. 3e), the alternating freezing-thawing cycles favour regolith development. Gelifluction (and solifluction during thawing) in the upper parts of the gullies and on the steep slopes surrounding the gullies leads to an accumulation of material in 

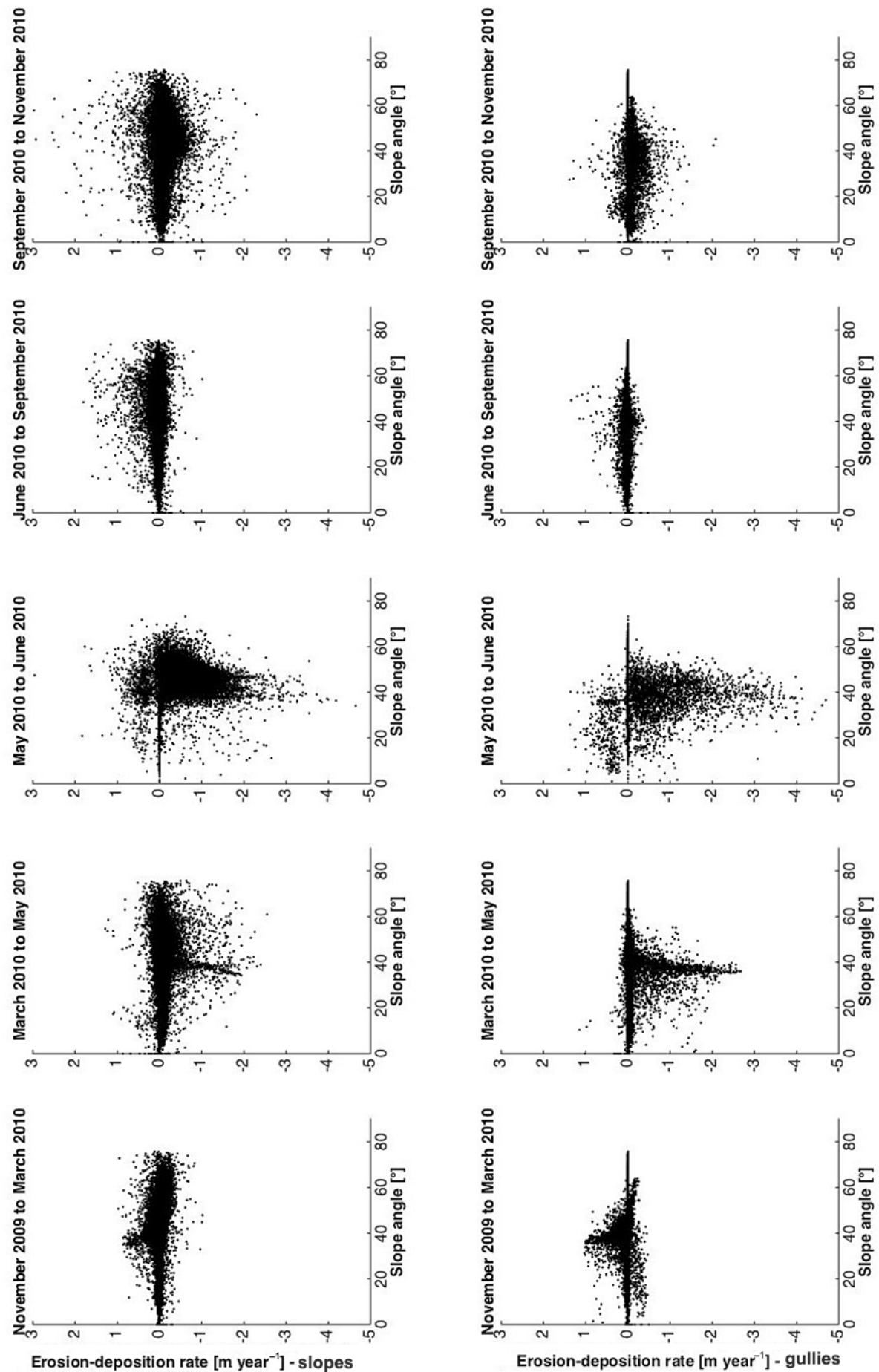

Figure 4. Vertical change over time vs. slope angle. Rates are calculated from a $10 \mathrm{~cm}$ grid average of original DoDs and divided by the time separating the two lidar acquisitions. Slope angle in degrees, calculated in ArcGIS on a $10 \mathrm{~cm}$ DEM of June 2010. Top graphs of the left column show rates for slopes and the right column for gullies and adjacent ( $20 \mathrm{~cm}$ or closer) pixels (see the Supplement for similar graphs showing vertical change in absolute value vs. slope angle).

the lower parts of the gullies. The soil surface changes are mostly located on the south-facing slopes of the watershed. A higher number of freezing-thawing cycles results in a higher amount of regolith that can be mobilized (Maquaire et al., 2002; Raclot et al., 2005) and therefore more production of sediment along the slopes. 
During the spring seasons, (Fig. 3a), the sediment accumulated during winter in the main gullies is transported at the outlet of the catchment. This transport is generally limited to the two main gullies. Erosion is transport-limited and consequently only the gullies with the larger contributing surface are drained.

During late spring to early summer rainy seasons (Fig. 3b), rainfall can be relatively intense (Mathys et al., 2005). Consequently, the secondary rills, gullies, and the steepest slopes can be strongly affected by Hortonian runoff and the weathered regolith developed during winter can be washed out. The south-facing slopes are more prone to such a type of erosion pattern as more weathered sediment is produced during winters. Often, small deposition levees are observed in the lower (flatter) parts of the gullies.

During the summer seasons (Fig. 3c), characterized by relative drought except for the occurrence of a few thunderstorms, there is very little erosion activity. The same small gullies and rills as those affected by the late spring erosion pattern continue to be eroded in their steepest parts, while deposits and small levees are formed in their lower parts. Most of the loose weathered regolith has already been washed away. The less frequent but more intense storms observed in this season do not impact the erosion pattern, now sedimentlimited.

During the autumn seasons (Fig. 3d), the rainfall pattern is characterized by long and low-intensity events with some very short intense precipitation leading to slow soil wetting and consecutive increase in soil moisture. Progressively, a new layer of regolith is created, and in most of the rills and gullies, sediment transport is reactivated.

\subsection{Topographic influences}

DoD value changes over time are plotted against topographic proxies. The DoD values are displayed for slopes (left) and gullies (right) for each period (Figs. 4-6; in the Supplement, similar figures provide DoD values plotted against topographic proxies).

The seasonal cycle is clearly visible on the slope angle vs. DoD rate of change (Fig. 4), with the deposition-erosion cycle during the year and regolith expansion. Autumn and winter periods see an accumulation of loose sediments in the gullies, which are then eroded in late spring or early summer. We may suspect that in winter, the cycle is a slow continuous process and in late spring to early summer it was subject to an intensive short erosive event (this can be also an artefact because of the unequal time between surveys). In those gullies, both maximum deposition (November to March) and erosion (March to May) are reached at a slope angle of $35^{\circ}$, a critical slope for granular material (Gotzinger et al., 2007) and thus also for the deposits most susceptible to erosion. The summer and autumn periods show limited change, both in gullies and slopes.
The slope aspect proxy (Fig. 5) also shows the annual cycle and different behaviour between slopes and gullies. South- and south-west-facing slopes are more susceptible to increased erosion and deposition and probably expansion (particularly in the November to March and June to September periods).

The upstream contributing area shows the same seasonal pattern, with deposition (gullies) and expansion (slopes) in winter and erosion in early summer. From June to September, DoD values are inversely proportional to UCA in slopes, with gullies showing smaller changes (Fig. 6).

TOBIA index values show that the Roubine gully is mainly composed of orthoclinal slopes (52\% of area) and steepened escarpments (39\% of area), consistent with its east-west incision into east-dipping marls, but no link can be seen between erosion activity and structural outcropping conditions. The intersection between bedding and topography is very similar across the whole catchment.

\subsection{Quantification of seasonal sediment budget changes}

For the quantification of the seasonal sediment budget changes, the TLS data of the years 2007 and 2008 have been ignored because TLS data did not cover the largest possible area of the catchment but others did. The eroded volume trend estimated with TLS (Table 2) is in agreement with the integrated measurement of coarse-sediment transfer at the outlet trap (Table 3; Fig. 7). The difference is in an acceptable range (5.5\% for the period from 14 April 2009 to 4 November 2010 on the total cumulated volumes).

The maximum eroded volume is produced for the period March-June 2010 (Table 2) with a sediment transfer of ca. $8.7 \mathrm{~m}^{3}\left(35 \mathrm{~m}^{3} \mathrm{yr}^{-1}\right.$ or $\left.26 \mathrm{~mm} \mathrm{yr}^{-1}\right)$ out of the catchment. For the period November 2009-March 2010 (Table 2), more than $1.2 \mathrm{~m}^{3}\left(3.1 \mathrm{~m}^{3} \mathrm{yr}^{-1}\right.$ or $\left.2.3 \mathrm{~mm} \mathrm{yr}^{-1}\right)$ are transported but most of the volume is redistributed within the catchment because the rainfall was not intense enough to transport the sediment out of the catchment. The autumns 2009 and 2010 (Table 2) are characterized by moderate sediment transfers with respectively $0.9 \mathrm{~m}^{3}\left(4.1 \mathrm{~m}^{3} \mathrm{yr}^{-1}\right.$ or $\left.3.1 \mathrm{~mm} \mathrm{yr}^{-1}\right)$ and $1.6 \mathrm{~m}^{3}$ $\left(13.7 \mathrm{~m}^{3} \mathrm{yr}^{-1}\right.$ or $\left.10.3 \mathrm{~mm} \mathrm{yr}^{-1}\right)$ transported out of the catchment based on TLS observations, with some significant rainfall events. It must be noted that the event of 21 October 2009 led to a deposit of $1.7 \mathrm{~m}^{3}$ (more than $1 \mathrm{~cm}$ eroded over the whole catchment) in the sediment trap, with an intensity reaching $0.8 \mathrm{~mm} \mathrm{~min}^{-1}$ and rain totalling $36 \mathrm{~mm}$ during the day. The three main events of 2010 are of a different kind. The first occurred during the first 14 days of May, reaching a total of precipitation of $155 \mathrm{~mm}$. The main precipitation event occurred on 10 May, which reached $1 \mathrm{~mm} \mathrm{~min}^{-1}$ (during $4 \mathrm{~min}$ more than $0.5 \mathrm{~mm} \mathrm{~min}^{-1}$ ) after antecedent precipitation since May 1 of $70 \mathrm{~mm}$. A volume of nearly $3 \mathrm{~m}^{3}$ was transferred out of the catchment during that period. The second occurred on 15 June 2010, with a daily rainfall of $69 \mathrm{~mm}$ 

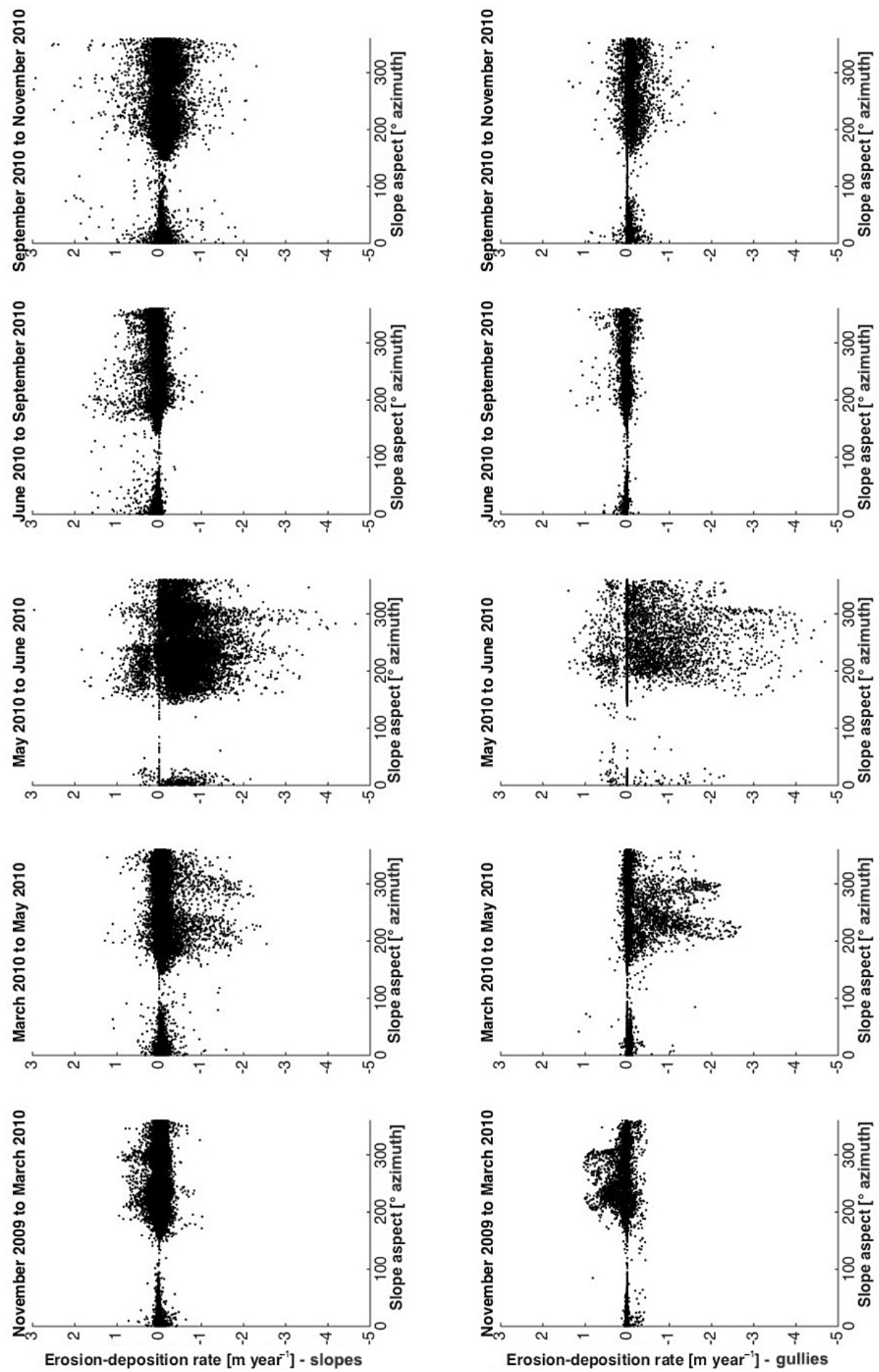

Figure 5. Vertical change over time vs. slope aspect. Rates are calculated from a $10 \mathrm{~cm}$ grid average of original DoDs and divided by the time separating the two lidar acquisitions. Slope aspect in degrees, calculated in ArcGIS on a $10 \mathrm{~cm}$ DEM of June 2010 . Top graphs of the left column show rates for slopes and the right column for gullies and adjacent $(20 \mathrm{~cm}$ or closer) pixels (see the Supplement for similar graphs showing vertical change in absolute value vs. slope aspect). 

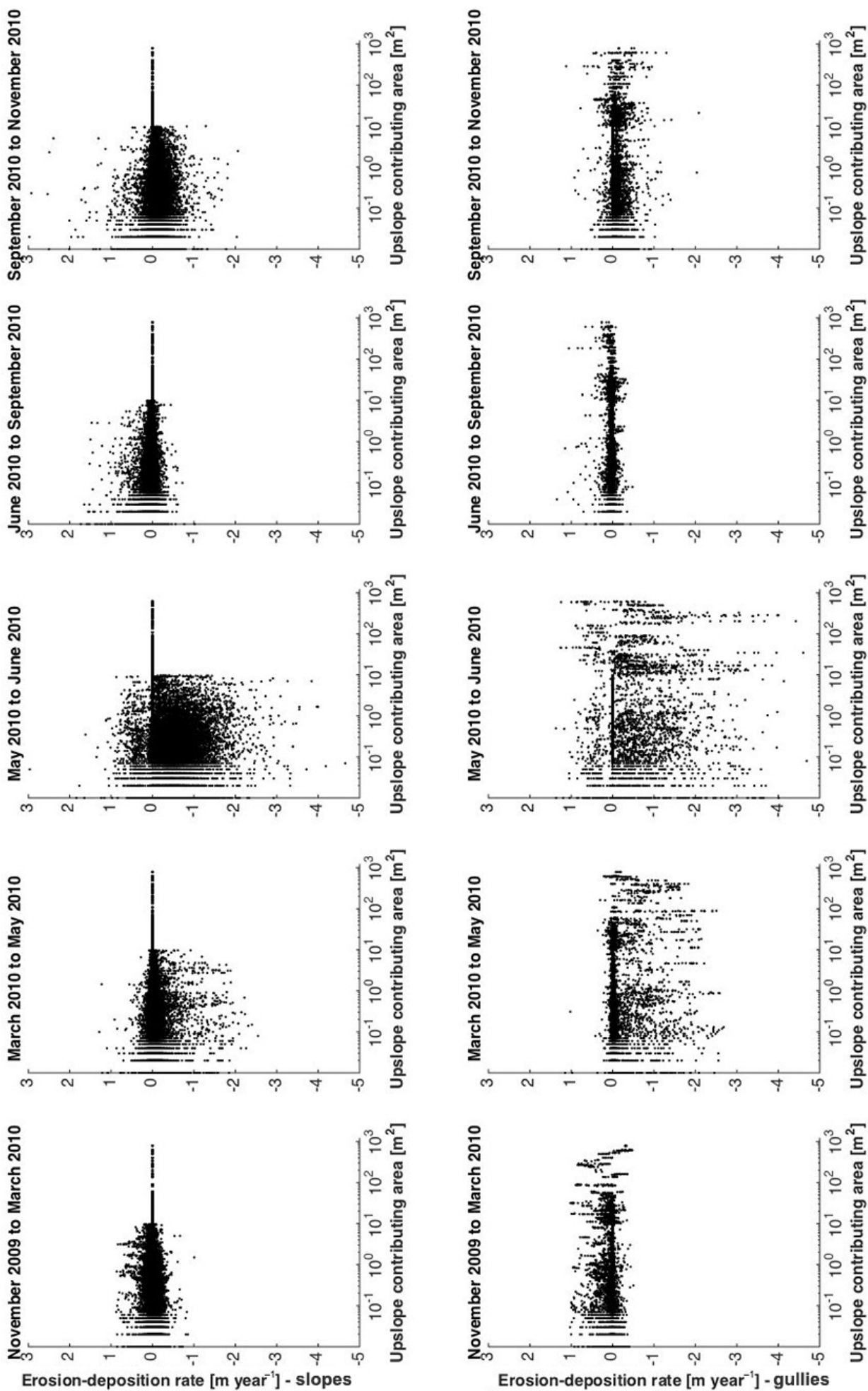

Figure 6. Vertical change over time vs. upslope contributing area. Rates are calculated from a $10 \mathrm{~cm}$ grid average of original DoDs and divided by the time separating the two lidar acquisitions. Upslope contributing area in square metres, calculated in ArcGIS on a $10 \mathrm{~cm}$ DEM of June 2010. Top graphs of the left column show rates for slopes and the right column for gullies and adjacent $(20 \mathrm{~cm}$ or closer) pixels (see the Supplement for similar graphs showing vertical change in absolute value vs. contributing area). 


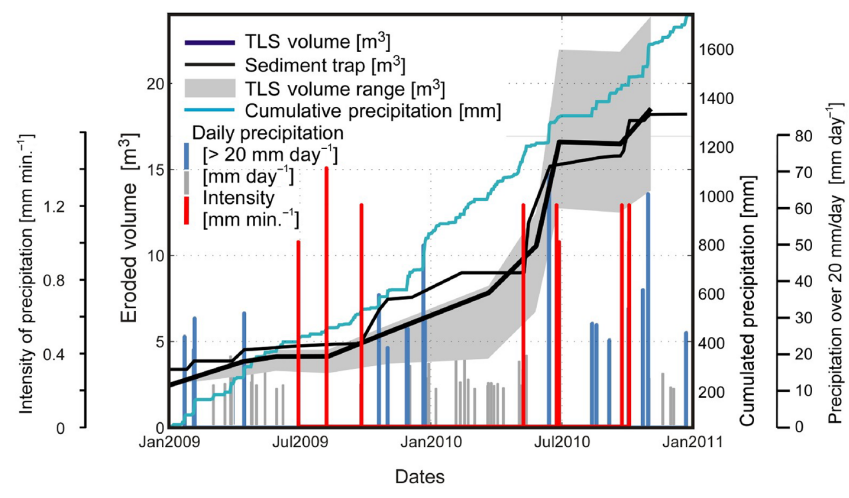

Figure 7. Cumulated TLS-measured volumes (in bold black line) against cumulated calibration on sediment-trap-measured volumes (thin black line) for the years 2009 and 2010. In addition, the cumulative precipitation is shown as well as the daily precipitation events (in grey) and the main daily precipitation events that are considered as significant in red $\left(>20 \mathrm{~mm} \mathrm{day}^{-1}\right)$ and the largest-intensity event above $10 \mathrm{~mm} \mathrm{~min}^{-1}$ sampled with a tipping-bucket rain gauge. The initial sediment delivery is not zero because we used the storage in the sediment trap of the previous period as the initial value.

and rainfall the day before being $5.5 \mathrm{~mm}$, including an intensity maximum of $0.8 \mathrm{~mm} \mathrm{~min}^{-1}$. The maximum intensity on the 15 th was $0.6 \mathrm{~mm} \mathrm{~min}^{-1}$ after $42 \mathrm{~mm}$ of antecedent precipitation (from 14 June). It appears that this event was able to transport out of the catchment around $3 \mathrm{~m}^{3}$ measured in the trap and estimated at $6 \mathrm{~m}^{3}$ from TLS for the period 28 May23 July 2010. The last important event occurred on 4 October 2010, with a small but intense $12 \mathrm{~mm}$ rain event. The intensity reached $1 \mathrm{~mm} \mathrm{~min}^{-1}$ during $10 \mathrm{~min}$. The measurements by TLS $\left(1.6 \mathrm{~m}^{3}\right)$ and within the sediment trap $\left(1.7 \mathrm{~m}^{3}\right)$ were very close.

\section{Discussion}

\subsection{Interpretation}

With the TLS measurements, the balance value is negative when the erosion sediment volume is larger than the deposited sediment volumes. The presence of shadow areas in the TLS scans affects the TLS sediment budget as erosionprone areas can be hidden from the laser pulse. When these erosion-prone areas are hidden, the deposited sediments can be considered to be more important than the erosion volumes. The balance is therefore positive, as for example for the period June-September 2010 (Table 2). The shadow areas are usually located in the upper parts of the slopes and are often very steep and close to the crests of the catchment; these areas are highly productive sources of sediments. Therefore, it is hypothesized that the sediment budget is underestimated for most of the periods. The value of eroded volumes based on the sediment trap is increased by $20 \%$ to include the suspended sediments; otherwise the true erosion rates are un- derestimated. In addition, although the swelling or inflation of the regolith surface (Bechet et al., 2015) can have an influence on the georeferencing, it was not possible to quantify it at the level of the Roubine catchment. Nevertheless, it has been shown that the unweathered black marl density is $2650 \mathrm{~kg} \mathrm{~m}^{-3}$, while the regolith density can be as small as $1300 \mathrm{~kg} \mathrm{~m}^{-3}$, but it varies greatly in space and time according to the presence of local discontinuities (Maquaire et al., 2003; Travelletti et al., 2012). The measurements of the densities of the black marl deposited in the sediment trap usually vary from 1500 to $1800 \mathrm{~kg} \mathrm{~m}^{-3}$ (Mathys et al., 1996). By calibrating the TLS with sediment trap volume, the swelling or inflation of the regolith has been indirectly quantified by the observed changes of eroded material density. The density of the regolith when it is mostly in a disturbed state possesses a density of $1500 \mathrm{~kg} \mathrm{~m}^{-3}$, which gives a $\sim 75 \%$ volume increase compared to the bedrock density $2650 \mathrm{~kg} \mathrm{~m}^{-3}$. Moreover, $2325 \mathrm{~kg} \mathrm{~m}^{-3}$ corresponds to an expansion of $14 \%$. For the lowest measured value $\left(1300 \mathrm{~kg} \mathrm{~m}^{-3}\right)$, the increase is more than $100 \%$. In addition, the slope-erosion relationship shows some positive values in winter, indicating an increase in volume.

Also, topographic height differences smaller than the TLS threshold of $1.8 \mathrm{~cm}$ are not integrated into the sediment budget although they could contribute to an important sediment volume because of their possible widespread occurrence, mainly during the summer storms that trigger important Hortonian runoff. This limitation also influences the sediment budget by underestimating the total volume of erosion. But because of the coherence of the results, we consider that it can be a base for an interpretation of the catchment erosional system.

\subsection{Conceptual model}

All the results can be synthesized in a conceptual model describing the seasonal pattern of erosion and deposition and quantifying the volumes of sediment transfer (Fig. 8). This seasonal pattern is controlled by the rainfall distribution and the availability of sediment during each period. The results may thus be different depending on the year, but the sequence will not change; only the time lapses between major erosive events will change.

During the spring and summer seasons, the sediment transfer consists of the erosion of the weathered loose regolith layer on the slopes and a mobilization of the transient storages of accumulated sediments in the rills and gullies (right graphs in Figs. 4, 5, and 6) if no exceptional rainfall event occurs. But during the late spring and early summer, intense rainfall events produce very high erosive events (Figs. 4, 5, and 6 and the Supplement). Most of the sediments exiting the Roubine catchment are a product of the winter weathering. It appears to be a slow process, with rates of change smaller than in the other periods, but it is longer, and as a consequence the total changes are important but can be an arte- 


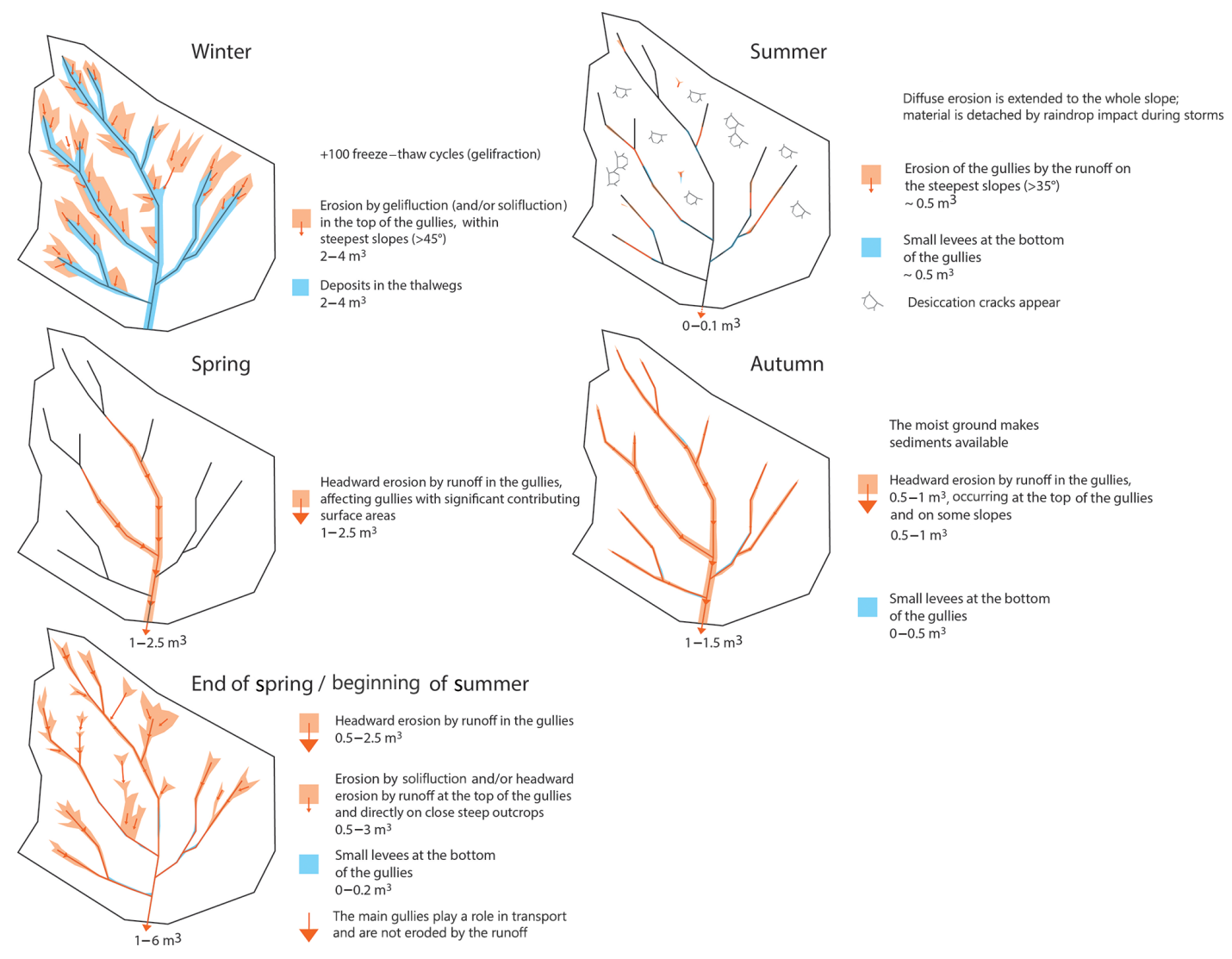

Figure 8. Conceptual model describing the seasonal pattern of erosion and deposition and quantification of the volumes of sediment transfer at La Roubine catchment.

fact due to the time period between surveys (see and compare Figs. 4-6 and the Supplement). The erosion progressively evolves from a transport-limited (at the beginning of spring) to a supply-limited (in summer) pattern. However, diffuse erosion may happen during intense summer storms as heavy drops may detach and displace small particles, creating sparse local erosion and deposition. Hortonian runoff may also be generated, but its effects could not be measured with the TLS technique as a higher accuracy is necessary. In the autumn seasons, a new layer of loose regolith is progressively created (Fig. 4, left graphs), and if an intense rainfall event has occurred before in summer, as is usually the case, then the quantity of available sediment is limited (Figs. 4, 5, 6, right graphs).

The main events summarized above all occurred after more than $9 \mathrm{~mm}$ rainfall, which is also the limit for initiating runoff in a larger similar catchment (Laval) after more than 5 antecedent dry days (Mathys et al., 2000). That threshold is lower if the dry period is smaller than 5 days. These events either possess an intensity that reaches $1 \mathrm{~mm} \mathrm{~min}^{-1}\left(=60 \mathrm{mmh}^{-1}\right)$, which is the limit to trigger MDFs (Yamakoshi et al., 2009), or have immediate antecedent rainfall that has saturated the soil. This last situation permits the earlier initiation of runoff if it is coupled with significant precipitation, which permits an intense short erosive event with lower intensities such as $0.6 \mathrm{~mm} \mathrm{~min}^{-1}$ to be induced. The sediment yield is controlled by the availability of the upper part of the regolith and by the grain size distribution. Mathys (2006) indicated that in the area of Draix, the four first centimetres of the regolith contain $45 \%$ clay and silts and the next four centimetres contain $35 \%$ clays and silts. This shows that the size of material transported will change with time, i.e. the antecedent period in terms of rainfall and climate. In addition, it has been shown that in the beginning of the year, the sediment moves but stays partially within the catchment, concentrating the material in the gullies. This non-linearity is supported by the fact that the quantity and type of material mobilized depends on the duration and intensity of the rainfall. Partitioning of the total load exported from the catchment shows that at low discharge the suspended material part ranges between 0 and $40 \%$, whereas it is close to $40 \%$ for higher discharge (Mathys, 2006). This indicates that only high-intensity precipitation can mobilize the whole upper part of the regolith and/or split marl plates into smaller particles, whereas small intensities depend on 
the grain size of this upper part of the regolith at the time of the event.

It is also clear that sediment transfer depends on the material available (Bardou and Jaboyedoff, 2008). The winter period, because of frost-thaw cycles and low rainfall intensity, permits the creation and accumulation of weathered material. The relatively low rainfall intensities of these winter periods permit the mobilization of partial material that remains within the slope and gullies. It is also interesting to note that the most active zones within the gullies, both regarding erosion and deposition, are located around a slope angle of $35^{\circ}$, which corresponds to the angle of repose of dry granular material (Gotzinger et al., 2007). This indicates that sediment transfer from the slopes to the gullies is mostly controlled by local dry transport.

The difference between rills and inter-rill erosion depends on rainfall intensity and antecedent rainfall amounts. The accumulated material in the rills can be mobilized by moderate rainfall intensities for fine material, while inter-rills need intense precipitation and/or a well-developed upper part of the regolith. In winter, the upper regolith probably only moves a short distance on a centimetre scale by small mass movements (Bechet et al., 2015) and on a metre scale by MDFs. In spring, the material accumulated in the rill is washed away, and later the inter-rills and rills with small contributing areas can be eroded and the material transported outside the catchment. Autumn permits the material accumulated in the main rills during summer to be cleaned. This scheme may change depending on the future climate if less precipitation occurs and only intense rainfall events remain. The system could then concentrate the full erosion in one or a few events. A warmer climate may also reduce the number of frost-thaw cycles and thus also reduce the depth of the regolith layer generated every year. But in any case, the seasonality that leads to weathered material will remain in the cold period, which is the main producer of sediments that can be mobilized.

\subsection{Hillslope activity processes}

The observed high production of loose regolith is mainly caused by the alternating of freezing-thawing and wettingdrying cycles, which is the key process controlling the weathering of black marl slopes (Maquaire et al., 2002; Brochot et Meunier, 1994). At the end of the winter season, a thick layer of loose regolith can be accumulated in the areas of the slopes and gullies with slope angles around $35^{\circ}$. The south-facing slope is characterized by a higher number of weathering cycles than the north-facing slope (Maquaire et al., 2002), leading to the observed more active erosiondeposition processes. Because we consider only the freezing and thaw cycles, the south-facing slopes experience more cycles than the north-facing ones, but the gullies located in the south-facing slope are equivalent to those in the north-facing slope (Rovera and Robert, 2005). However, the north-facing slopes present higher depths of frozen soils. In addition, it has been demonstrated that erosion rates increase with increasing slope angle on bare marls (Lopez-Saez et al., 2001). This is not clearly the case here; in fact the regions close to gullies are more subject to erosion because of previous accumulation. In addition, the structures can play a role. The slopes cutting the bedding by an angle close to $90^{\circ}$ are more prone to erosion than dip slopes or those following the top of bedding (Esteves et al., 2005). This is mainly caused by the alternation of more competent and weaker bedding, the latter controlling the erosion of the competent beds. Dip slopes are less sensitive to weak layers except if they outcrop at the top. However, this behaviour cannot be confirmed in La Roubine, as not all outcropping types are present.

Another point is runoff seasonal changes. It is transportlimited in spring, which is probably mainly caused by the limited amount of intense rainfall during this season. Looking at the flow accumulation values, the gullies that have a contributive area smaller than $100 \mathrm{~m}^{2}$ are not able to mobilize material if the daily rainfall or the intensity is not sufficient. To give an order of magnitude, if an intense event of a few minutes at $0.5 \mathrm{~mm} \mathrm{~min}^{-1}$ occurs on saturated ground (on these $100 \mathrm{~m}^{2}$ ) and assuming $100 \%$ runoff, the discharge will be $0.5 \mathrm{~L} \mathrm{~min}^{-1}$, which probably permits the erosion of the rills. In addition, the effect of runoff and rainfall intensity is not straightforward. The erosion rate depends first on the material available, second on the rainfall intensity, and third on the slope. The summer season does not include the two first conditions. But low-intensity rainfall participates in the cycle of erosion by allowing drying and wetting plus micro-slope movements, which weather the regolith more and transfer mass locally. As we observed, the slope surfaces evolve dynamically throughout the yearly cycle. In the spring season, the regolith observed in the gullies has a popcorn structure defined as an "Expansion [...] accompanied by the development of cracks separated by micro-humps" (Gutiérrez, 2005) and therefore a lower density compared to the unweathered black marls. In the summer season, sedimentary and structurally thin crusts can develop at the surface of the regolith because of the wetting (Malet et al., 2003). In the absence of shallow mass movements, the lower part of the slopes are, generally, eroded by runoff at the same rate as the interfluves and the upper part the slopes; this system yields to relatively constant slope gradient values over time (Descroix and Mathys, 2003).

\section{Conclusion}

By their strong and rapid responses to climate forcing, the black marls of Draix-Bléone are a good basis for the analysis of erosive processes. This article confirmed the results of previous works, i.e. the strong dependence on the seasons and the cycle of processes (Jacome, 2009), the issues linked to the sediment trap measurements, and the estimation of den- 
sity of the regolith (Mathys, 2006). The prediction of the responses of small mountain watersheds to climatic events is improved.

TLS has proved to be an appropriate tool to monitor gully erosion while being easily reproducible and accurate all at once. It also allowed working on the centimetre scale with success. The method used to create and compare DEMs proved very effective to map and quantify topographic changes, but some difficulties have still to be solved to fully quantify the sediment transfer.

The TLS permits us mainly to locate the different processes. This first results show that the rainfall pattern, i.e. time series, intensity, and duration, controls the sediment delivery sequence, but the process of weathering (mainly freezing and thawing) is fundamental to providing material for either suspended load or bedload. The interplay of rainfall and weathering creates the seasonal pattern. The complete erosion processes seem to apply during winter, and they are slow transport-limited processes by weathering (swelling). However, they affect important volumes and later in summer the behaviour is sediment-limited, while from late spring to early summer the erosion is very intensely controlled by intense short erosive events induced by intense rainfalls. Further investigation could also focus on the dry granular transport and its role in the accumulation of sediments during winter periods.

Here we have shown the limits of the methods. Further investigations with HRDEM must be carefully set up in order to avoid errors from data acquisition. In addition, this surface monitoring must be coupled with more variables monitored simultaneously during the event, such as soil moisture, swelling, rain drop size, grain size distribution, and soil density. Furthermore, a density map of the regolith inside the catchment throughout the year (season by season) would be a great help to improve the TLS volume correction, but this will require physical intervention in the catchment to install sensors and collect samples.

Such procedures are not possible in the Roubine catchment, which must not be disturbed by human activity. A new small catchment (Roubinette) has thus been instrumented on the site of Draix, which will permit the installation of instruments inside the watershed itself. The next step will be to acquire TLS data during a storm event.

\section{Data availability}

The data may be accessible on direct request to the corresponding author because no structured repository exists at present.

\section{The Supplement related to this article is available online at doi:10.5194/esurf-4-781-2016-supplement.}

Acknowledgements. We would like to thank the IRSTEA who let us work on their field and who gave us valuable data. Thanks to the GIS Draix and particularly to S. Klotz (IRSTEA). We dedicate this paper to the first author, Jacques Bechet, who died in a snow avalanche on 28 March 2015. The content of this paper is an expression of his great ingenuity, curiosity and passion for research he shared with his co-worker Julien Duc. We will ever remember his enthusiasm.

Edited by: G. Sofia

Reviewed by: three anonymous referees

\section{References}

Abellán, A., Jaboyedoff, M., Oppikofer, T., and Vilaplana, J. M.: Detection of millimetric deformation using a terrestrial laser scanner: experiment and application to a rockfall event, Nat. Hazards Earth Syst. Sci., 9, 365-372, doi:10.5194/nhess-9-3652009, 2009.

Antoine, P., Giraud, A., Meunier, M., and van Asch, T. W. J.: Geological and geotechnical properties of the 'Terres Noires' in southeastern France: weathering, erosion, solid transport and instability, Eng. Geol., 40, 223-234, 1995.

Ballais J. L. : Apparition et évolution du modelé de roubines dans les Préalpes du Sud: l'exemple de Draix, in: Actes du colloque "La montagne méditerranéenne" (Aix-en-Provence, 1998), edited by: Riser, J., Études de Géographie Physique, no. XXVIII, 105-108, 1999.

Bardou, E. and Jaboyedoff, M.: Debris Flows as a Factor of Hillslope Evolution controlled by a Continuous or a Pulse Process?, in: Landscape Evolution: Denudation, Climate and Tectonics over Different Time and Space Scales, edited by: Gallagher, K., Jones, S. J., and Wainwright, J., Geol. Soc. London Spec. Publ., 63-78, 2008.

Bechet, J., Duc, J., Jaboyedoff, M., Loye, A., and Mathys, N.: Erosion processes in black marl soils at the millimetre scale: preliminary insights from an analogous model, Hydrol. Earth Syst. Sci., 19, 1849-1855, doi:10.5194/hess-19-1849-2015, 2015.

Besl, P. J. and McKay, N. D: A method for registration of 3-d shapes, IEEE T. Pattern Anal., 14, 239-256, 1992.

Betts, H. D. and DeRose, R. C.: Digital elevation models as a tool for monitoring and measuring gully erosion, Journal of Applied Earth Observation and Geoinformation, 1, 91-100, 1999.

Brochot, S. and Meunier, M.: Erosion en badlands dans les Alpes du sud: synthèse, in: Compte-rendu de recherches no. 3, BVRE de Draix, Cemagref Editions, 141-174, 1995.

Chen, Y. and Medioni, G.: Object modeling by registration of multiple range images. Image Vis. Comput., 10, 145-155, 1992.

DeRose, R. C., Gomez, B., Marden, M., and Trustrum, N. A.: Gully erosion in Mangatu Forest, New Zealand, estimated from digital elevation Models, Earth Surf. Proc. Land., 23, 1045-1053, 1998.

Descroix, L. and Gautier, E.: Water erosion in the southern French Alps: climatic and human mechanisms, Catena, 50, 53-85, 2002.

Descroix, L. and Mathys, N.: Processes, spatio-temporal factors and measurements of current erosion in the French southern Alps: A review, Earth Surf. Proc. Land., 28, 993-1011, 2003.

Descroix, L. and Olivry, J. C.: Spatial and temporal factors of erosion by water of black marl in the badlands of the French Southern Alps, Hydrolog. Sci. J., 47, 227-242, 2002. 
Esteves, M., Descroix, L., Mathys, N., and Lapetite, J. M.: Soil hydraulic properties in a marly gully catchment (Draix, France), Catena, 63, 282-298, 2005.

Grotzinger, J., Jordan, T. H., Press, F., and Siever, R.: Understanding Earth, 6th, Freeman and Company, New York, 579 pp., 2007.

Gutiérrez, M.: Climatic Geomorphology, Elsevier, Amsterdam, 760 pp., 2005.

Innovmetric Software Inc.: Polyworks, version 9.1.8., available at: http://www.innovmetric.com (last access: 1 October 2016), 2010.

Jaboyedoff, M., Metzger, R., Oppikofer, T., Couture, R., Derron, M.-H., Locat, J., and Turmel, D.: New insight techniques to analyze rock-slope relief using DEM and 3D-imaging cloud points: COLTOP-3D software, in: Rock mechanics: Meeting Society's Challenges and demands (Vol. 1), edited by: Eberhardt, E., Stead, D., and Morrison, T., Taylor \& Francis, 61-68, 2007.

Jaboyedoff, M., Oppikofer, T., Abellán, A., Derron, M.-H., Loye, A., Metzger, R., and Pedrazzini, A.: Use of LIDAR in landslide investigations: a review, Nat. Hazards, 61, 5-28, doi:10.1007/s11069-010-9634-2, 2012.

Jacome, A.: MNT à très haute résolution spatiale pour la représentation 3D des ravines d'érosion de montagne, Thèse de Doctorat, Université Montpellier II, Sciences et Techniques du Languedoc, 2009.

Kromer, R., Abellán, A., Hutchinson, J., Lato, M., Edwards, T., and Jaboyedoff, M.: A 4D filtering and calibration technique for small-scale point cloud change detection with a Terrestrial Laser Scanner, Remote Sens., 7, 13029-13052, doi:10.3390/rs71013029, 2015.

Légier, A.: Mouvement de terrain et évolution récente du relief dans la région de Barcelonnette (Alpes-de-Haute-Provence), $\mathrm{PhD}$ thesis, Grenoble I University, 163 pp., 1977.

Lopez Saez, J., Corona, C., Stoffel, M., Rovéra, G., Astrade, L., and Berger, F.: Mapping of erosion rates in marly badlands based on a coupling of anatomical changes in exposed roots with slope maps derived from LiDAR data, Earth Surf. Proc. Land., doi:10.1002/esp.2141, 2011.

Malet, J.-P., Auzet, A. V., Maquaire, O., Ambroise, B., Descroix, L., Esteves, M., Vandervaere, J.-P., and Truchet, E.: Soil surface characteristics influence on infiltration in black marls: application to the Super-Sauze earthflow (southern Alps, France), Earth Surf. Proc. Land., 28, 547-564, 2003.

Maquaire, O., Ritzenthaler, A., Fabre, D., Thiery, Y., Truchet, E., Malet, J.-P., and Monnet, J.: Caractérisation des profils de formations superficielles par pénétrométrie dynamique à énergie variable: application aux marnes noires de Draix (Alpes-de-HauteProvence, France), Comptes-Rendus Geosciences, 334, 835$841,2002$.

Maquaire, O., Malet, J.-P., Remaître, A., Locat, J., Klotz, S., and Guillon, J.: Instability conditions of marly hillslopes: towards landsliding or gullying? The case of the Barcelonnette Basin, South East France, Eng. Geol., 70, 109-130, 2003.

Mathys, N.: Analyse et modélisation à différentes échelles de mécanismes d'érosion et de transport de matériaux solides. Cas des petits bassins versants de montagne sur marne (Draix, Alpes-de-Hautes Provence), PhD Thesis, Institut National Polytechnique de Grenoble, 2006

Mathys, N., Brochot, S., and Meunier, M.: L'érosion des terres noires dans les Alpes du Sud: contribution à l'estimation des valeurs annuelles moyennes (bassins versants expérimentaux de Draix, Alpes-de-Haute-Provence, France), CEMAGREF, Grenoble, 1996.

Mathys, N., Brochot, S., and Lacheny, B.: Genèse des crues et érosion dans les petits bassins versant de montagne: observations et résultats obtenus sur les bassins versants expérimentaux de Draix (Alpes-de-Haute-Provence), Association Forêt Méditerranéenne, XXI, 182-190, 2000.

Mathys, N., Brochot, S., Meunier, M., and Richard, D.: Erosion quantification in the small marly experimental catchment of Draix (Alpes Alpes-de de-Haute Haute-Provence, France). Calibration of the ETC rainfall-runoff-erosion model, Catena, 50, 527-548, 2003.

Mathys, N., Klotz, S., Esteves, M., Descroix, L., and Lapetite, J.M.: Runoff and erosion in the Black Marls of the French Alps: observations and measurements at the plot scale, Catena, 63, 261-281, 2005.

Meentemeyer, R. K. and Moody, A.: Automated mapping of conformity between topographic and geological surfaces, Computers and Geoscience, 26, 815-829, 2000.

Meunier, M. and Mathys, N.: Panorama synthétiques des mesures d'érosion effectuées sur trois bassins du site expérimental de Draix (Alpes-de de-Haute Haute-Provence, France), CEMAGREF, Grenoble, 1995.

Olivier, J. E.: Les fortes crues d'août 1997 à Draix: d'un printemps sec à des records de charges solides, Les bassins versants expérimentaux de Draix laboratoire d'étude de l'érosion en montagne - actes du séminaire, Draix Le Brusquet Digne, 22-24 octobre 1997, Cemagref Editions, Antony, 53-63, 1999.

Olivry, J.-C. and Hoorelbeck, J.: Erodibilité des terres noires de la vallée du Buëch (France, Alpes du Sud), Cahier ORSTOM Série Pédologie, 25, 95-110, ISSN: 0029-7259, 1989.

Oostwoud Wijdenes, D. J. and Erzinger, P.: Erosion and sediment transport on steep marly hillslopes, Draix, Haute-Provence, France: an early experimental field study, Catena, 33, 179-200, 1998.

Perroy, R. L., Bookhagen, B., Asner, G. P., and Chadwick, O. A.: Comparison of gully erosion estimates using airborne and ground-based LiDAR on Santa Cruz Island, California, Geomorphology, 118, 288-300, 2010.

Phan, T. S. H. and Antoine, A.: Mineralogical and geotechnical characterization of the "Black Lands" of the South-East of France, having in view road applications. Proceedings of the VIIth International Congress of the Intenational Association of Eng Geol., Lisboa, vol. 2. Balkema, Rotterdam, 961-966, 1994.

Puech, C., Thommeret, N., Kaiser, B., Bailly, J.-S., Jacome, A., Rey, F., and Mathys N.: MNT à très haute résolution dans les modelés fortement disséqués : des données aux tests d'application, Géomorphologie 2/2009, 2009.

Raclot, D., Puech, C., Mathys, N., Roux, B., Jacome, A., Asseline, J., and Bailly, J.-S.: Photographies aériennes prises par drone et modèle numérique de terrain : apports pour l'observatoire sur l'érosion, Géomorphologie, 2005, 7-20, 2005.

Richard, D.: les Les bassins versants experimentaux expérimentaux de Draix (04) : éetude de l'érosion et du transport solide torrentielle à partir de mesures in situ, CEMAGREF, Grenoble, 218228, 1997. 
Rovera, G. and Robert, Y.: Conditions climatiques hivernales et processus d'érosion périglaciaires dans les badlands marneux de Draix, GEographie Physique et Quaternaire, 59, 31-48, 2005.

Schürch, P., Densmore, A. L., Rosser, N. J., Lim, M., and McArdell, B. W.: Detection of surface change in complex topography using terrestrial laser scanning: application to the Illgraben debris-flow channel, Earth Surf. Proc. Land., 36, 1847-1859, 2011.

Shan, J. and Toth, K.: Topographic laser ranging and scanning: principles and processing, CRC Press, Taylor \& Francis Group, LLC, UK, 2008.

Shepard, D.: A Two-Dimensional Interpolation Function for Irregularly Spaced Data, Proceedings of 23rd ACM National Conference, New York, 1968, 517-523, doi:10.1145/800186.810616, 1968.
Travelletti, J., Sailhac, P., Malet, J.-P., Grandjean, G., and Ponton, J.: Hydrological response of weathered clay-shale slopes: water infiltration monitoring with time-lapse electrical resistivity tomography, Hydrol. Process., 26, 2106-2119, doi:10.1002/hyp.7983, 2012.

Yamakoshi, T., Mathys, N., and Klotz, S.: Time-lapse video observation of erosion processes on the black marls badlands in the Southern Alps, France, Earth Surf. Proc. Land., 34, 314-318, 2009.

Yamakoshi, T., Mathys, N., and Klotz, S.: Visual observation of erosion processes on the Black Marl badlands in the southern Alps, France, in: Weathering as a Predisposing Factor to Slope Movements, edited by: Calcaterra, D. and Parise, M., Geological Society, London, Eng. Geol. Special Publications, 23, 201-212, 2010. 